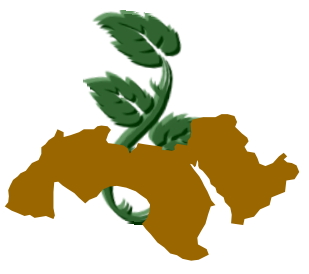

Arab Univ.

J. Agric. Sci., Ain Shams Univ., Cairo, 22(1), 85-92, 2014

\title{
FARMERS RESOURCES USE EFFICIENCY IN SOME HORTICULTURE CROPS PRODUCTION IN NORTH WESTERN COAST AREA
}

\author{
Soha M. Eldeep ${ }^{1}$ and Dalia E. Abozied ${ }^{1}$ \\ 1- Agricultural Economic Dept., Socio-Economic Division, Desert Research Center, EL-Mataria, \\ Cairo Egypt \\ Correspondence author: email: dr_soha11@yahoo.com
}

Keywords: Resources use efficiency, Gross margin, Horticulture crops

\begin{abstract}
The research estimated the efficiency of resource use among north western coast farmers in Marsa matrouh governorate using a sample of 200 respondents that were randomly selected; Interview schedules and structured questionnaires were administered to elicit information from the farmers. Data were analyzed using gross margin analysis, production, costs functions and resource use efficiency. The results for Tomato showed that, the regression analysis indicated that, R2 was highly significant at $1 \%$ level with the value of $90 \%$. This implied that $90 \%$ of the total variations in Tomato yield is explained by combine influence of all the explanatory variables (farm inputs) in the regression equation analysis, Gross margin analysis showed that farmers made profit (gross margin= 11810 LE / feddan). The resource use efficiency result showed that, the farm resources (cultivated area, organic manure, machines and labour) were under-utilized for Tomato production in the study area, The results for Cantaloupe showed that, The regression analysis indicated that, $\mathrm{R} 2$ was highly significant at $1 \%$ level with the value of $91 \%$. This implied that $91 \%$ of the total variations in Cantaloupe yield is explained by combine influence of all the explanatory variables (farm inputs) in the regression equation analysis, Gross margin analysis showed that farmers made profit (gross margin = 15870 LE/feddan), the resource use efficiency result showed that two farm resources (cultivated area and labour )were under -utilized and one farm resource( $\mathrm{N}$ fertilizer) was over- utilized for Cantaloupe production in the study area.
\end{abstract}

\section{INTRODUCTION}

Most of the recent gains in agricultural production have resulted from expanding the area of land cultivated and not increasing the production per unit of land area. The implications are not just a decline in per feddan production efficiency but a use of more marginal land with ever increasing negative impacts on the natural resource base Increases in efficiency per feddan are the result of improved technologies and access to inputs. The sustainable way to increase efficiencies is to create capacity to generate new technologies. Horticulture has a special role. The dependence on low cash generating commodities for agriculture cannot generate enough income for rural inhabitants. Horticultural crops can be a salvation for such a situation, another point here is related to the dependence on cereals as the main and probably the sole constituent of diet. Malnutrition is expected due to the lack of vitamins and other food supplements. Horticultural crops provide the necessary supplements to assure a balanced diet for a healthy population. Horticulture also offers potentials for small value-adding activities that could help in generating income for rural areas and create opportunities. Horticultural crop production systems can also improve productivity and water use efficiency. Once water is collected or harvested, there is no supplementary irrigation for a lower value crops. It is advised to utilize the water in the most intensive cultivation systems using high value crops to produce enough cash to sustain good living. In the case of arid environments, the point in using it for best utilization of soil and water resources is a must Information related to on farm water use is available in a wide range of publications. It is quite difficult to sum it in few lines. Nev- 
ertheless, it is important to stress upon the different patterns of agricultural activities and their relative differences in water use efficiency.

North Western coast area one of essential parts of Egypt for sustainable development. The area stretches westwards from Abo Laho in east to Marsa Mattroh and west of El-Negela basin (about $80 \mathrm{Km}$ length and $20 \mathrm{~km}$ average width) is considered one of the most promising regions for development. The selected area have a population of about 300,000 and can possess a good agricultural expansion, due to its favorable soil and water potentials, in addition to its mild weather. The area depends mainly in groundwater where the salinity ranges between 2000 to $25000 \mathrm{ppm}$ where the water type is brackish to extremely saline. The water samples in the promising area of investigation are more than 100 water points and the depth to water is from $4.22 \mathrm{~m}$ to $104 \mathrm{~m}$. The rate of water discharge from this area is $8000 \mathrm{~m}^{3} /$ day. Therefore, using the proper desalination process can make this quantity of water useful in different proposes and extended the crowded population to another places far from the delta and valley delta of Nile.

Horticultural crops include tree and vine (fruit/nut) crops, vegetables, and ornamental crops It has the potential for social impact (employment creation and income generation) as well as sustainability (better economic use of water).

Tomato and Cantaloupe an important and most cultivated crops from horticulture crops in North Western Coast area, Tomato cultivated area reached 2025 feddan from total winter cultivated area which reached 3102 feddan by $65.3 \%$ in winter (2011-2012) and Cantaloupe cultivated area reached 6230 feddan from total summer cultivated area which reached 35845 feddan by $17.4 \%$ in summer (2012).

\section{Study Objectives}

The objectives were to examine the gross margin analysis, factors that impacts and determines the study crops production, assess the production function and cost function to determine the productive volume maximizing profit for each crop and measure the resource use efficiency in North Western coast area.

\section{Research methodology Data collection}

This research was carried out in North Western Coast area at Marsa Matrouh governorate. The source of data used was basically primary data. This involved the use of an interview schedule with a well designed structured questionnaires administered to the farmers, A total of two hundred (200) farming households were selected and interviewed for the research, Crops used in this research tomato for( 2011-2012)winter season and cantaloupe for (2012) summer season represented most cultivated crops from horticulture crops in the research area .

\section{Analytical Technique}

The analytical tools that were used for this include gross margin analysis, the simple and physic regression had been used to estimate the production function, Cost functions and resource use efficiency.

\section{Gross margin analysis}

A gross margin is simply an estimate or a budget of the income and costs associated with a specific crop or activity in a farming business. Gross margin analysis is used to determine which crops are more profitable than others.

A gross margin is calculated using the following formula:

Gross Margin for Activity = Gross Income for Activity - Variable Costs for activity

Gross Income for Activity: This represents all the income for growing and marketing a particular crop and is normally the total sales value for a particular crop.

Variable Costs for Activity: This represents all the expenses for growing a particular crop and can include: pumping costs, casual labour, seed, fuel and oil, contractors, harvesting, packing and freight costs. They are called variable costs because they vary with the amount of area planted, therefore if the area of this particular crop was zero, then the variable costs would also be zero.

Gross Margin: A gross margin is the amount of cash left over from growing any particular crop. It is not an absolute measure of profit but it will determine the best financial result when a number of different crop alternatives are compared. The other set of costs that are omitted from a gross margin analysis are the 'overhead' or fixed costs. Overhead costs are those costs which do not change depending on the crop that is grown. 
Gross margin model is expressed as follows:

$$
G M=T R-T V C
$$

Where:

$\mathrm{GM}=$ Gross margin (LE/Feddan).

$\mathrm{TR}=$ Total revenue or total value of output from the research crops enterprise (LE/Feddan). It is the product of average output per feddan multiplied by the market price.

The price used was open market price.

TVC $=$ Total variable cost or the costs that are specific in producing (sorghum) output (LE/Feddan).

TVC varies according to output and are incurred on variable inputs. This includes cost of inputs like seeds, fertilizer, and harvesting, processing, labour cost (hired/family).

\section{Production Function Analysis}

Regression model was used to examine inputoutput relationship and the implicit form of the model is given by:

$$
Y=f\left(X_{1}, X_{2}, X_{3}, X_{4}, X_{5}, X_{6}, X_{7}, U i\right)
$$

\section{Where:}

$Y=$ Output from crop Production (ton)

$\mathrm{X} 1$ = cultivated area (feddan)

$\mathrm{X} 2$ = quantity of manure (cubic meter)

$\mathrm{X} 3=\mathrm{k}$ fertilizer (effective unit)

$X 4=$ machine work (hour/day)

$\mathrm{X} 5$ = labor (man/day)

$\mathrm{X} 6=\mathrm{N}$ fertilizer (effective unit)

$\mathrm{X} 7$ = quantity of irrigated water (cubic meter)

$\mathrm{U}=$ Error term.

The explicit form of this function takes the following forms:

$$
\begin{gathered}
Y=a+b_{1} X_{1}+b_{2} X_{2}+b_{3} X_{3}+b_{4} X_{4}+b_{5} X_{5}+b_{6} \\
X_{6}+b_{7} X_{7}+U i .
\end{gathered}
$$

$\mathrm{Y}=$ estimative value of the crop produced quantity in ton during the observing. $X_{1}=$ the cultivated area per feddan during the observing, $X_{2}=$ the quantity of manure in cubic meter during the observing, $X_{3}=k$ fertilizer in the effective unit during the observing, $X_{4}=$ machine work (hour/day) during the observing, $X_{5}=$ labor (man/day) during the observing, $X_{6}=\mathrm{N}$ fertilizer in the effective unit during the observing, $X_{7}=$ the quantity of irrigated water in cubic meter during the observing.

\section{Analysis of Resource use Efficiency}

Resource use efficiency was obtained from the production function analysis. Efficiency is general- ly defined as the quantity of output $(\mathrm{Y})$ per unit of input $(x)$ used in the production process, that is, the average physical productivity (APP).

In order to ascertain whether resources were efficiently utilized, the marginal value product (MVP) of the variable inputs used was computed and compared with their input prices. The following ratio was used to compute the efficiency of resource use.

Where:

$$
\mathrm{R}=\frac{\mathrm{MVP}}{\mathrm{MFC}}
$$

$\mathrm{R}=$ Efficiency ratio

MVP = Marginal value product (value added to tomato output due to the use of additional unit of input)

MFC = Marginal factor cost (cost of unit of a particular resource).

But MVP is estimated as:

$\mathrm{MVP}=\operatorname{MPP}_{\mathrm{xi}} \mathrm{P}_{\mathrm{y}}$

$\operatorname{MPP}_{\mathrm{xi}}=\frac{\partial \mathrm{y}}{\partial \mathrm{xi}}$

$\operatorname{MPP}_{x i}$ is the marginal physical product of a unit of input $\mathrm{X}_{\mathrm{i}}$,

$\mathrm{P}_{\mathrm{y}}$ is the price of output.

As regards the resource use efficiency,

whenever

MVPxi > MFCxi there is under utilization of resource $x i$

MVPxi < MFCxi there is over utilization of resource $\mathrm{xi}$

MVPxi = MFCxi there is optimum utilization of resource $x i$

\section{Cost Function Analysis}

Regression model was used to examine inputoutput relationship and the implicit form of the model is given by:

$$
T c=b_{0}+b_{1} q+b_{2} q^{2}+b_{3} q^{3}+u \text {. }
$$

Where:

Tc =total production cost.

$\mathrm{Q}=$ output production.

$\mathrm{U}=$ Error term.

\section{RESULTS AND DISCUSSION}

The result of the gross margin analysis was presented in Table (1). Costs incurred on various resources used and the profits obtained from the sales of the produce were estimated based on the 
market price at the period under consideration, a gross return was calculated by multiplying the total quantity of produce harvested by the price of output sold. The average gross return is 20000 LE /feddan.

For cost of production, total variable cost and total fixed cost were considered in order to calculate the total cost of production. The total variable cost includes cost of labour, chemicals, fertilizer and seeds while total fixed costs includes cost of renting land, and depreciation on farm tools. The straight line method, which assumed a constant rate of annual depreciation, was used to calculate the depreciation on farm tools.

The labour used consists of family, hired labour. The wage rate varies slightly depending on the operation to be performed on the farm. The average wage rat of wage is $60 \mathrm{LE} / \mathrm{man}$-day was used to calculate the total labour cost. The total cost of labour accounts for $30.7 \%$ of the variable cost, The cost of the total production inputs was 4170 LE/feddan, The Equipment Operating Costs were $1500 \mathrm{LE} / \mathrm{feddan}$, The gross margin and net farm income (profit) were 11810,10610 LE/feddan respectively.

Table 1. Gross margin and returns for Tomato

\begin{tabular}{|c|c|}
\hline Item & (LE/feddan) \\
\hline Total Revenue & 20000 \\
Input costs & 4170 \\
Equipment Operating Costs & 1500 \\
labour & 2520 \\
Total variable cost & 8190 \\
Gross margin & 11810 \\
Total fixed cost & 1200 \\
Net Farm Income/Profit (NFI) & 10610 \\
\hline
\end{tabular}

Source: collected and calculated from questionnaire data, 2012

The Statistical Estimate for Production Functions for Tomato

There are many algebraic images could be used in drive the productive functions. Also many attempts may be executed to choose the image, which its results is fit to the economic and statistic base. This study has depended on the multiple regression, on one hand, the input of the productive function representing in the cultivated area, manure, inorganic fertilizers, herbicide, seeds, la- bor and machine work. On the other hand, the quantity of feddan production in ton had been used for the output of function, during tomato winter season (2011-2012).

$Y=$ estimative value of the Tomato produced quantity in ton during the observing. $X_{1}=$ the cultivated area per feddan, during the observing. $X_{2}=$ the quantity of manure in cubic meter during the observing, $X_{3}=k$ fertilizer in the effective unit during the observing, $X_{4}=$ machine work (hour/day), during the observing $X_{5}=$ labor (man/day) during the observing, $X_{6}=N$ fertilizer in the effective unit, during the observing, $X_{7}=$ the quantity of irrigated water in cubic meter, during the observing.

The formula No. (1) showed a statically significance and direct relationship between feddan productivity of tomato and cultivated area, quantity of manure, labor, machine work and quantity of irrigated water. if these elements changed by $1 \%$ the gross production will increase about $90 \%$.

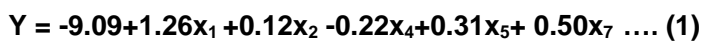

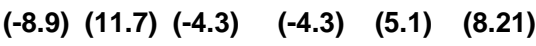

$$
R^{2}=0.90 \quad F=35
$$

The Statistical Estimate for cost Function for Tomato

The formula No. (2) showed the function of the total costs through which the volume maximizing profit by equalizing the function of marginal costs and average costs had been estimated, during the season 2011-2012. This provided the productive volume maximizing profit was around 37.8 tons, When comparing the volume of maximizing profit with average actual production of the tomato sample which amounted about 20 tons/feddan, we find the average actual production is less than the volume that maximize the profit. This indicates the inefficiency of using the available agricultural resources during that phase of production.

$$
\begin{aligned}
& \mathrm{TC}=97549.08+3611.66 q-47.71 q^{2} \\
& \begin{array}{lll}
(7.4) \quad(3.6) \quad(6.6)
\end{array} \\
& R^{2}=0.89 \quad F=30 \\
& M C=3611.66-95.42 q=0 \\
& 3611.66=95.42 q \\
& q=37.8
\end{aligned}
$$

\section{Resource Use Efficiency}

In determining the efficiency of the inputs used, Marginal Value Product and the Marginal Factor 
Cost (MVP and MFC) were determined. The marginal factor cost which is the unit price for the variable inputs used in tomato production in the research area.

From Table (2), it was observed that all the production inputs were under-utilized, as the MVP was higher than the MFC. This means that increase use of this inputs will lead to further increase in output. Specifically for every amount spent on cultivated area, organic manure, machines and labour the returns from tomato will increase.. Labour (family and hired) is very scarce in the area probably because people now prefer to train their children in school that will eventually pull them away from agriculture ,that explain the difference between average actual production and average production that maximize the profit.

This is in conformity with the study of Mesike. (2009) which stated that agricultural resources are under-utilize due to the cost of obtaining the resources.

Table 2. Marginal Value Product (MVP), Marginal Factor Cost (MFC) of production inputs and resources use efficiency

\begin{tabular}{|l|c|c|c|}
\hline resources & MVP(LE) & MFC $($ LE $)$ & R=MVP/MFC \\
\hline $\begin{array}{l}\text { cultivated } \\
\text { area }\end{array}$ & 1260 & 1200 & 1.05 \\
$\begin{array}{l}\text { Organic } \\
\text { manure } \\
\text { machine }\end{array}$ & 124 & 100 & 1.24 \\
$\begin{array}{l}\text { work } \\
\text { labour }\end{array}$ & 316 & 60 & 4.4 \\
\hline
\end{tabular}

Source: collected and calculated from questionnaire data, 2012

Table (3) presented, the result of the gross margin analysis that Costs incurred on various resources used and the profits obtained from the sales of the produce were estimated based on the market price at the period under consideration ,a gross return was calculated by multiplying the total quantity of produce harvested by the price of output sold. The average gross return is 25000 LE /feddan.

For cost of production, total variable cost and total fixed cost were considered in order to calculate the total cost of production. The total variable cost includes cost of labour, chemicals, fertilizer and seeds while total fixed costs includes cost of renting land, and depreciation on farm tools. The straight line method, which assumed a constant rate of annual depreciation, was used to calculate the depreciation on farm tools.

The labour used consists of family, hired labour. The wage rate varies slightly depending on the operation to be performed on the farm. The average wage rat of wage is $60 \mathrm{LE} / \mathrm{man}$-day was used to calculate the total labour cost. The total cost of labour accounts for $26.3 \%$ of the variable cost. The cost of the total production inputs was 5180 LE/feddan. The Equipment Operating Costs were1550 LE/feddan. The gross margin and net farm income (profit) were 15870, 14670 LE/feddan respectively.

Table 3. Gross margin and returns for Cantaloupe

\begin{tabular}{|c|c|}
\hline Item & (LE/feddan) \\
\hline Total Revenue & 25000 \\
Input costs & 5180 \\
Equipment Operating Costs & 1550 \\
labour & 2400 \\
Total variable cost & 9130 \\
Gross margin & 15870 \\
Total fixed cost & 1200 \\
Net Farm Income/Profit (NFI) & 14670 \\
\hline
\end{tabular}

Source: collected and calculated from questionnaire data, 2012

\section{The Statistical Estimate for Production Func- tions for cantaloupe}

There are many algebraic images could be used in drive the productive functions. Also many attempts may be executed to choose the image, which its results is fit to the economic and statistic base. This study has depended on the multiple regression, on one hand, the input of the productive function representing in the cultivated area, manure, inorganic fertilizers, herbicide, seeds, labor and machine work. On the other hand, the quantity of feddan production in ton had been used for the output of function, during cantaloupe summer season (2012).

$Y=$ estimative value of the cantaloupe produced quantity in ton during the observing. $X_{1}=$ the cultivated area per feddan, during the observing. $X_{2}=$ the quantity of manure in cubic meter, during the observing, $X_{3}=k$ fertilizer in the effective unit, during the observing. $X_{4}=$ machine work (hour/day), during the observing, $X_{5}=$ labor (man/day), during the observing. $X_{6}=\mathrm{N}$ fertilizer in the effective unit, 
during the observing. $X_{7}=$ the quantity of irrigated water in cubic meter, during the observing.

The formula No. (3) showed a statically significance and direct relationship between Feddan productivity of cantaloupe and cultivated area, labor, $\mathrm{N}$ fertilizer and quantity of irrigated water. if these elements changed by $1 \%$, the gross production will increase about $91 \%$.

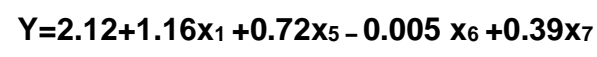

\section{$\begin{array}{lllll}(3.7) & (7.1) & (2.7) & (-2.03) & (20.7)\end{array}$}

$$
R^{2}=0.91 \quad F=57
$$

\section{The Statistical Estimate for cost Function for cantaloupe}

The formula No. (4) showed the function of the total costs through which the volume maximizing profit by equalizing the function of marginal costs and average costs had been estimated, during the season 2012. This provided the productive volume maximizing profit was around 33.1 tons When comparing the volume of maximizing profit with average actual production of the cantaloupe sample which amounted about 17 tons/feddan, we find the average actual production is less than the volume that maximize the profit. This indicates the inefficiency of using the available agricultural resources during that phase of production.

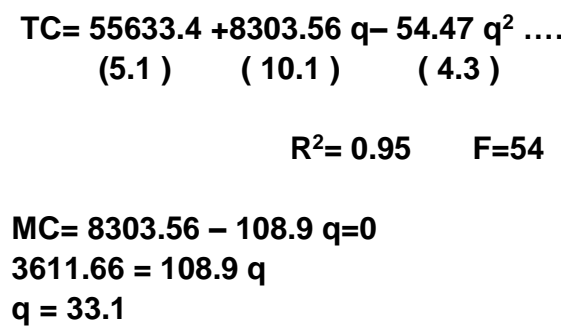

\section{Resource Use Efficiency}

In determining the efficiency of the inputs used, Marginal Value Product and the Marginal Factor Cost (MVP and MFC) were determined The marginal factor cost which is the unit price for the variable inputs used in tomato production in the study area.

From Table (4), Comparison of the ratio of the MVP to MFC shows that two resulting ratio were greater than unit cultivated area and labour indicating that the input were under used or being under utilized on the farms during the cropping Cantaloupe in season hence increasing its rate of use will increase output and profit level. Similarly, one resulting ratios was less than unity $\mathrm{N}$ fertilizer indicating that the inputs were excessively used or over- utilized hence decreasing quantity of the inputs use will increase output and profit level, that explain the difference between average actual production and average production that maximize the profit, This is in conformity with the study of V.B. Taru (2008) which stated that the hypothesis that resources are not efficiently utilized.

Table 4. Marginal Value Product (MVP), Marginal Factor Cost (MFC) of production inputs and resources use efficiency

\begin{tabular}{|l|c|c|c|}
\hline Resources & MVP(LE) & MFC(LE) & R=MVP/MFC \\
\hline cultivated & 1740 & 1200 & 1.45 \\
area & & & \\
N fertilizer & 7.5 & 150 & 0.05 \\
labour & 1080 & 60 & 18 \\
\hline
\end{tabular}

Source: collected and calculated from questionnaire data, 2012

Output of Tomato in the research area was significantly influenced by cultivated area, quantity of manure, labor, machine work and quantity of irrigated water applied. The efficiency analysis indicated underutilization of cultivated area, organic manure, machines and labour while the gross margin analysis showed that the farmers made profit about (11810 LE/feddan), on other hand Output of Cantaloupe in the research area was significantly influenced by cultivated area, labor, $\mathrm{N}$ fertilizer and quantity of irrigated water. The efficiency analysis indicated underutilization cultivated area, labour and overutilization of $\mathrm{N}$ fertilizer while the gross margin analysis showed that the farmers made profit about (15870 LE / feddan).

\section{REFERENCES}

Abang, S.O. and Agom D.I. (2004). Resource use efficiency of small-holder farmers: the case of cassava producers in Cross River State, Nigeria. J. Food, Agriculture and Environment, vol (2):87-97.

Mesike, C.S., Owie, O.E.D. and Okoh, R.N. (2009). Resource-Use Efficiency and Return to Scale in Smallholders rubber farming System in Edo State, Nigeria. J. Sustainable Tropical Agricultural Research, 28(3):183-186. 
Fasasi, A.R. (2006). Resource use efficiency in yam production in Ondo state, Nigeria. Medwell online Agricultural Journal, 1(2): 36-40.

Mohammed, B.T., Aduba, J.J., Jilasaya, I. and Ozumba, I.C. (2011). Farmers resources use Efficiency in sorghum production in NIGERIA, J. Agricultural Economics, 5(2):21-30.

Okon, U.E. and Enete, A.A. (2009). Resource Use Efficiency among Urban Vegetable Farmers in Akwa lbom State, Nigeria, Tropicultura, 27(4): 211-217.
Upton, M. (1996). The economy of topical farming systems. Cambridge University Press. Cambridge, UK.

Umoh, G.S. (2006). Resource use efficiency in urban farming: an application of stochastic frontier production function. International J. Agriculture and Biology, 8(1): 37-44.

Taru, V.B., Kyagya, I.Z., Mshelia, S.I. and Adebayo, E.F. (2008). Economic Efficiency of Resource Use in Groundnut Production in Adamawa State of Nigeria, World J. Agricultural Sciences, 4(s): 896 -900. 